DOI: $10.1515 /$ rpp-2015-0041

$\mathrm{PhD}$ in Public Administration, Senior Researcher, OLENA SLYUSARENKO Institute of Higher Education of the National Academy of Educational Sciences, Ukraine Address: 9 Bastionna St., Kyiv, 01014, Ukraine E-mail: Slyusarenko_o@ukr.net;

\title{
THE VISIONS OF WORLD-CLASS UNIVERSITIES
}

\section{ABSTRACT}

The visions of the top 26 world-class universities of the first 30 in the Shanghai ranking list have been evaluated and compared with the missions of the world's top 20 universities. Applying the content analysis, a group of 48 keywords, which describe the essence of these visions, has been revealed. The average amount of keywords in one vision is 51. According to the relevant characteristics, the missions are three times shorter (respectively 15 and 18 words). All keywords in missions, except one, are present in the list of words for visions. The main keywords for visions are "world", "research', "students", "education" and "knowledge", each of these words is present in half and more than three quarters of visions. For missions such words are "education', "research", "knowledge" and "create", and have the same degree of use. The main content differences relating to visions and missions occur due to a lower word frequency (less significance). Comparison of visions and missions using 20 characteristic parameters shows that in quantitative terms, except the range of normalized frequencies for a certain number of institutions and the average frequency of keyword use, visions substantially prevail the relevant characteristics of missions (from 1,3 to 5,0 times). Regarding the qualitative structure of visions and missions - they are almost identical (mismatch within 0,9-1,2 times). This can be explained by the fact that mission in general as the generic purposes of the top institutions are more specific, unambiguous and stable in formulations, so to speak, statutory and the degree of their interuniversity variations is less. At the same time, the strategic visions of their implementation are more diverse and creatively formulated like a sort of expected predictions; therefore, they are less accurate and more approximate, and of course they are frequently reviewed in the process of development.

Key words: visions, missions, keywords, main keywords, qualitative vision composition, the world's top universities, Shanghai ranking list.

\section{INTRODUCTION}

Research and innovative character of global progress raises a special interest upon certain peculiarities of functioning and development of stable leaders and locomotives of this progress. Such exemplary drivers of social progress are, first of all, the institutions of higher education (hereinafter - institutions, universities) of extra class identified by the international rankings like the Academic Ranking of World Universities (ShanghaiRanking) (Academic Ranking of World Universities, 2014; Луговий, Калашнікова, Слюсаренко, Таланова, 2013; Слюсаренко, 2014). Given this, it is much more important to know the guiding ideas and principles, targets and strategies, slogans, mission and visions of the world's top universities.

According to the previously performed study the key characteristics of mottos and missions of the world's top 30 universities in mentioned Shanghai-Ranking are elucidated. The findings of this study in 2014 were sent for publication to the Intercultural Education 
magazine (Poland). Other similar studies on the stated problem are not represented in modern specialist literature.

\section{THE AIM OF THE STUDY}

The purpose of the article is to clarify the essential characteristics of visions of the top 26 universities in the Shanghai ranking list (Academic Ranking of World Universities, 2014) of the top 30 universities and compare them with previously identified mission parameters of such institutions.

\section{THEORETICAL FRAMEWORK AND RESEARCH METHODS}

To achieve this goal, the content and Spearman's correlation analysis and also appropriate vision generalizations of the top 26 universities have been made, first of all, to identify the keywords that reflect the essence of these visions.

The frequency method (approach), under which it is believed that the more a certain word is used in the formulation of different visions the more significant it is, has been applied to determine the keywords in visions.

\section{RESULTS}

In this paper $a$ vision is interpreted as a strategic vision of itself by any institution due to its capacity to most effectively and fully realize its own mission (purpose, generic calling) under certain institutional slogan (motto - short formulation of the main guiding idea, action program).

The institutional visions are taken directly from the universities' websites (About the Harvard Graduate School of Education, 2014; Caltech, 2014; Cornell University, 2014; ETH Zurich, 2014; Global Vision, 2015; Harvard Business School, 2014; Harvard School of Engineering and Applied Sciences, 2014; Harvard School of Public Health, 2014; Imperial College London, 2015; Johns Hopkins University, 2015; Kyoto University, 2015; Teacher College Columbia University, 2015; The University of California, San Diego, 2014; The University of Chicago Medicine and Biological Sciences, 2014; The University of Tokyo Charter, 2015; The will and the way, 2015; University of California, Berkley, 2014; University of California, Los Angeles, 2014; University of California, San Francisco, 2014; University of Chicago, 2014; University College London, 2014; University of Illinois, 2014; University of Michigan, 2015; University of Minnesota Twin Cities, 2015; University of Oxford, 2015; University of Pennsylvania, 2015; University of Toronto, 2014; University of Wisconsin Madison, 2015; University of Wisconsin, 2014; Yale Information Technology Services, 2014; Yale University. Office of the President, 2014; Yale University, 2014). Basically, the visions of the top $26(87 \%)$ universities in the Shanghai ranking list (Academic Ranking of World Universities, 2014) of the top 30 institutions were available there. In the 17 (65\%) of the 26 surveyed institutions visions are formulated at the institutional level as "visions" (Caltech, 2014; Cornell University, 2014; ETH Zurich, 2014; Global Vision, 2015; Imperial College London, 2015; Kyoto University, 2015; The University of California, San Diego, 2014; University of California, Berkley, 2014; University of California, San Francisco, 2014; University College London, 2014; University of Illinois, 2014; University of Michigan, 2015; University of Minnesota Twin Cities, 2015; University of Oxford, 2015; University of Pennsylvania, 2015; University of Wisconsin - Madison, 2015; University of Wisconsin, $2014)$, yet in $4(15 \%)$ institutions as a strategic vision of what should be the institution in general (University of Toronto, 2014; University of California, Los Angeles, 2014; The University of Tokyo Charter, 2015; The will and the way, 2015). In the case of the $3(12 \%)$ other universities (Harvard, Yale and Chicago) due to lack of a unified university's vision because of substantial diversity and autonomy of major university units the aggregated visions of several leading schools and other departments are evaluated (About the Harvard Graduate School of Education, 2014; Harvard Business School, 2014; Harvard School of 
Engineering and Applied Sciences, 2014; Harvard School of Public Health, 2014; The University of Chicago Medicine and Biological Sciences, 2014; University of Chicago, 2014; Yale Information Technology Services, 2014; Yale University. Office of the President, 2014; Yale University, 2014). Another two (8\%) universities (Columbia and Johns Hopkins) are represented by the visions of some main departments (Johns Hopkins University, 2015; Teacher College Columbia University, 2015) (see Table 1).

Table 1

A method for vision determination of the 26 top universities by Shanghai ranking

in 2014 and grouping of the institutions according to their stability ranking

\begin{tabular}{|c|c|c|c|c|c|}
\hline \multirow[b]{2}{*}{ № } & \multirow[b]{2}{*}{ Institution } & \multicolumn{3}{|c|}{ Definition of vision statement, the number of words } & \multirow[b]{2}{*}{$\begin{array}{l}\text { Rank group, } \\
\text { subgroup }\end{array}$} \\
\hline & & $\begin{array}{l}\text { Formulated by the } \\
\text { institution } \\
\text { as a vision or a } \\
\text { strategic vision of }\end{array}$ & \begin{tabular}{|c|} 
Vision \\
composition \\
of several \\
departments \\
\end{tabular} & \begin{tabular}{|c|} 
Vision of a \\
certain main \\
unit of the \\
institution \\
\end{tabular} & \\
\hline 1 & Harvard University & & $191^{*}$ & & $\begin{array}{c}\text { I stable, } \\
\text { degenerate }\end{array}$ \\
\hline 2 & Stanford University & - & - & - & \multirow{4}{*}{$\begin{array}{l}\text { II stable } \\
\text { (1st stable } \\
\text { subgroup) }\end{array}$} \\
\hline 3 & Massachusetts Institute of Technology & 12 & & & \\
\hline 4 & University of California, Berkeley & 18 & & & \\
\hline 5 & University of Cambridge & - & - & - & \\
\hline 6 & Princeton University & - & - & - & \multirow{5}{*}{$\begin{array}{c}\text { II stable } \\
\text { (2nd stable } \\
\text { subgroup) }\end{array}$} \\
\hline 7 & California Institute of Technology & 11 & & & \\
\hline 8 & Columbia University & & & 84 & \\
\hline $9-10$ & University of Chicago & & 94 & & \\
\hline $9-10$ & University of Oxford & 131 & & & \\
\hline 11 & Yale University & & 58 & & $\begin{array}{c}\text { II stable (3rd } \\
\text { stable subgroup, } \\
\text { degenerate) }\end{array}$ \\
\hline 12 & University of California, Los Angeles & $16^{*}$ & & & \multirow{15}{*}{$\begin{array}{l}\text { III quasi } \\
\text { stable }\end{array}$} \\
\hline 13 & Cornell University & 15 & & & \\
\hline 14 & University of California, San Diego & 7 & & & \\
\hline 15 & University of Washington & 27 & & & \\
\hline 16 & University of Pennsylvania & 81 & & & \\
\hline 17 & Johns Hopkins University & & & 14 & \\
\hline 18 & University of California, San Francisco & 5 & & & \\
\hline 19 & $\begin{array}{l}\text { Swiss Federal Institute } \\
\text { of Technology, Zurich }\end{array}$ & 93 & & & \\
\hline 20 & University College London & 60 & & & \\
\hline 21 & University of Tokyo & $69^{*}$ & & & \\
\hline $22-23$ & Imperial College London & 42 & & & \\
\hline $22-23$ & University of Michigan, Ann Arbor & 54 & & & \\
\hline $24-25$ & University of Toronto & $37^{*}$ & & & \\
\hline $24-25$ & University of Wisconsin - Madison & 48 & & & \\
\hline 26 & Kyoto University & 33 & & & \\
\hline 27 & New York University & - & - & - & \multirow{4}{*}{ IV unstable } \\
\hline $28-29$ & Northwestern University & $43^{*}$ & & & \\
\hline $28-29$ & $\begin{array}{l}\text { University of Illinois } \\
\text { at Urbana-Champaign }\end{array}$ & 27 & & & \\
\hline 30 & University of Minnesota, Twin Cities & 45 & & & \\
\hline & Total & \multicolumn{3}{|c|}{1315} & \\
\hline The & average number in 26 institutions & \multicolumn{3}{|c|}{51} & \\
\hline
\end{tabular}


Table 1 illustrates that institutions of stable, quasi-stable and unstable groupings within the first top 30 universities are represented by visions (Луговий, Калашніков, Слюсаренко, Таланова, 2013; Слюсаренко, 2014). In addition it is easy to see that the shortest vision statement consists of 5 words (University of California, San Francisco), the longest is of 191 words (Harvard University). The average vision statement of the 26 institutions consists of 51 words. All visions together contain 1315 words. At the same time, during calculation of the verbal vision composition the same word (or of the same root word), which is repeatedly mentioned in one vision formulation, has been accounted only one time. In addition, the words of a general (not specific) secondary importance, such as "university", "institute", "college", or when they reflect the name or location of the institution etc., are not taken into account.

The general list of 1315 words in institutional visions contained 438 (33\%) different words (not of the same root word and not close to synonyms), i.e. the average frequency of repeated words equals 3 . The frequency distribution of essentially different words is shown in Table 2.

Table 2

The frequency distribution of 438 different words in visions of the top 26 universities

\begin{tabular}{|c|c|c|c|c|}
\hline № & $\begin{array}{l}\text { Word frequency } \\
\text { data (normalized } \\
\text { to } 26 \text { ) }\end{array}$ & $\begin{array}{l}\text { The number of } \\
\text { words (percentage } \\
\text { of the total number } \\
\text { of different words) }\end{array}$ & Words (in English) & $\begin{array}{l}\text { Number of } \\
\text { institutions that } \\
\text { do not have } \\
\text { appropriate } \\
\text { words in their } \\
\text { visions }\end{array}$ \\
\hline 1 & 2 & 3 & 4 & 5 \\
\hline 1 & $20(0,77)$ & $1(0,2 \%)$ & world & $6^{\mathrm{a}}$ \\
\hline 2 & $19(0,73)$ & - & - & - \\
\hline 3 & $18(0,69)$ & - & - & - \\
\hline 4 & $17(0,65)$ & $1(0,2 \%)$ & research & $1^{\mathrm{b}}$ \\
\hline 5 & $16(0,62)$ & $1(0,2 \%)$ & students & $1^{\mathrm{b}}$ \\
\hline 6 & $15(0,58)$ & $1(0,2 \%)$ & education & 0 \\
\hline 7 & $14(0,54)$ & - & - & - \\
\hline 8 & $13(0,50)$ & $1(0,2 \%)$ & knowledge & 0 \\
\hline 9 & $12(0,46)$ & $3(0,7 \%)$ & global, lead, community & 0 \\
\hline 10 & $11(0,42)$ & $4(0,9 \%)$ & society, learning, our, innovation & 0 \\
\hline 11 & $10(0,38)$ & $4(0,9 \%)$ & nation, serve, create, distinctive & 0 \\
\hline 12 & $9(0,35)$ & $5(1,1 \%)$ & future, faculty, most, work, broad & 0 \\
\hline 13 & $8(0,31)$ & $13(3,0 \%)$ & $\begin{array}{l}\text { challenges, teaching, people, discovery, } \\
\text { diverse, making, economic, life, environment, } \\
\text { partnerships, academic, strive, development }\end{array}$ & 0 \\
\hline 14 & $7(0,27)$ & $14(3,2 \%)$ & $\begin{array}{c}\text { center, solutions, provide, public, } \\
\text { sciences, new, culture, collaboration, } \\
\text { enhance, scholarship, integrate, staff, } \\
\text { engage, advanced }\end{array}$ & 0 \\
\hline 15 & $6(0,23)$ & $15(3,4 \%)$ & $\begin{array}{l}\text { international, level, practice, strength, } \\
\text { recognized, ways, problems, impact, } \\
\text { experience, connect, important, great, } \\
\text { state, supporting, benefit }\end{array}$ & 0 \\
\hline 16 & $5(0,19)$ & $23(5,3 \%)$ & 23 another words & 0 \\
\hline 17 & $4(0,15)$ & $42(9,6 \%)$ & 42 another words & 0 \\
\hline
\end{tabular}


Порівняльна професійна педагогіка 5(2)/2015

Comparative Professional Pedagogy 5(2)/2015

\begin{tabular}{|c|c|c|c|c|}
\hline 1 & 2 & 3 & 4 & Continued \\
\hline 18 & $3(0,12)$ & $51(11,6 \%)$ & 51 another words & 0 \\
\hline 19 & $2(0,08)$ & $82(18,7 \%)$ & 82 another words & 0 \\
\hline 20 & $1(0,04)$ & $177(40,4 \%)$ & 177 another words & 0 \\
\hline \multicolumn{2}{|c|}{ Total } & $\mathbf{4 3 8 ( 1 0 0 \% )}$ & & 0 \\
\hline
\end{tabular}

Note: ${ }^{*}$ The visions without words of such and higher frequencies.

${ }^{a}$ The University of California, Los Angeles; the University of California, San Diego; the Johns Hopkins University; the University of Michigan, Ann Arbor; the University of Toronto and Kyoto University.

${ }^{\mathrm{b}}$ The Johns Hopkins University.

Table 2 illustrates that the frequency range for reproduction of certain words in different visions is between 1 and 20 . Half and more of the 26 visions contain five main words ("world", "research", "students", "education" and "knowledge"), in a descending order, having frequencies between 20 and 13. Normally three of them have been found in each of the surveyed visions. In total, the 48 words are found with frequencies from 7 (27\% of the 26 institutions) to $20(77 \%)$. They are to be recognized as the most important for vision characterization. The number of keywords is comparable with the average number of words (51) in one vision. Imaginary vision, which contains 48 keywords, can be recognized as a typical one for the top institutions located in the first 30 places in the Shanghai ranking list.

A comparison of average "lengths" in the formulation of actually ordinary visions (having 51 words) and imaginary typical visions (having 48 words) with related missions (having 18 and 15 words) shows that the visions are approximately three times longer than missions.

In Table 3 a set of vision characteristics of the top institutions are compared with a set of mission characteristics.

Table 3

Comparative characteristics of visions and missions of the world's top 30 universities in the Shanghai Academic Ranking of World Universities 2014

\begin{tabular}{|c|l|c|c|c|}
\hline \multirow{2}{*}{ № } & \multicolumn{1}{|c|}{ The characteristic parameter } & \multicolumn{1}{|c|}{ Visions } & Missions & $\begin{array}{c}\text { Parameters' correlation } \\
\text { between visions and } \\
\text { missions (times) }\end{array}$ \\
\hline 1 & \multicolumn{1}{|c|}{2} & 3 & 4 & 5 \\
\hline 1 & Number of institutions & 26 & 20 & 1,3 \\
\hline 2 & Number of words & 1315 & 357 & 3,7 \\
\hline 3 & The number of different words & 438 & 172 & 2,5 \\
\hline 4 & The average frequency of word use & 3,0 & 2,1 & 1,4 \\
\hline 5 & Word frequency range & $1-20$ & $1-15$ & 1,3 \\
\hline 6 & The average number of words & 51 & 18 & 2,8 \\
\hline 7 & The smallest number of words & 5 & 1 & 5,0 \\
\hline 8 & The largest number of words & 191 & 38 & 5,0 \\
\hline 9 & Keyword frequency range & $0,27-0,77$ & $0,25-0,75$ & 1,3 \\
\hline 10 & $\begin{array}{l}\text { The range of normalized frequencies } \\
\text { for keywords (26 and 20) }\end{array}$ & 48 & 15 & 1,0 \\
\hline 11 & $\begin{array}{l}\text { The number of different keywords } \\
\text { (in typical vision, mission) }\end{array}$ & 448 & 115 & 3,2 \\
\hline 12 & The number of keywords & $34 \%$ & $32 \%$ & 3,9 \\
\hline 13 & The average frequency of keyword use & & 1,1 \\
\hline 14 & The share of keywords among all words & & 1,1 \\
\hline
\end{tabular}




\begin{tabular}{|c|l|c|c|c|}
\hline \multicolumn{1}{|c|}{2} & 3 & 4 & 5 \\
\hline 1 & \multicolumn{1}{|c|}{ Continued } \\
\hline 15 & $\begin{array}{l}\text { The share of typical vision and mission words } \\
\text { among the average vision and mission words }\end{array}$ & $94 \%$ & $83 \%$ & 1,1 \\
\hline 16 & The share of keywords among different words & $11 \%$ & $9 \%$ & 1,2 \\
\hline 17 & $\begin{array}{l}\text { The average number of keywords in one vision, } \\
\text { mission }\end{array}$ & 17 & 6 & 2,8 \\
\hline 18 & $\begin{array}{l}\text { The share of one vision and mission keywords } \\
\text { among the total number of different keywords }\end{array}$ & $36 \%$ & $38 \%$ & 0,9 \\
\hline 19 & The share of keywords in one vision, mission & $34 \%$ & $32 \%$ & 1,1 \\
\hline 20 & $\begin{array}{l}\text { Number (percentage) of mission keywords } \\
\text { that coincide with vision keywords }\end{array}$ & 5 & 4 & 1,3 \\
\hline 21 & $\begin{array}{l}\text { Number of main keywords (found in half } \\
\text { and more than half visions, missions) }\end{array}$ & $53 \%)$ & \\
\hline
\end{tabular}

Table 3 shows that quantitatively the characteristic parameters of visions (numbers $1-9,11,12,17$ and 21) except the range of normalized frequencies for keywords and the average frequency of keyword use (numbers 10,13) substantially prevail the relevant characteristics of missions (from 1.3 to 5.0 times). Regarding the qualitative structure of visions and missions (numbers 14-16 and 18, 19 respectively) - they are almost identical (mismatch within $0,9-1,2$ times).

For this case, there is an explanation. After all, if missions of the world's top institutions are more specific, unambiguous and stable in formulations, so to speak, statutory, the strategic visions of their implementation are more diverse and formulated as the expected predictions, therefore, they are less accurate and more approximate, frequently reviewed in the process of development that is quite understandable. Sometimes, especially at Harvard University and the University of Tokyo, the visions are applied as an explanation of their missions (usually verbose). Although due to composition, the main (high-frequency) keywords in visions are close to such keywords in the missions. For example, three of the most high-frequency words in missions and visions are "education", "research", and "knowledge", and they are identical in both cases.

The main differences between the missions and visions start for the words that have a normalized frequency, which are present in less than half of the maximum possible cases (20 and 26). This is evident from Table 4.

Key words in the visions and missions of the world's top 30 universities in the Shanghai Academic Ranking of World Universities 2014

\begin{tabular}{|c|c|c|c|c|}
\hline \multirow[b]{2}{*}{ № } & \multicolumn{2}{|c|}{ Missions (of 20 institutions) } & \multicolumn{2}{|c|}{ Visions (of 26 institutions) } \\
\hline & $\begin{array}{c}\text { Word frequency } \\
\text { data (normalized } \\
\text { to } 20 \text { ) } \\
\end{array}$ & $\begin{array}{c}\text { Key words that are } \\
\text { common to missions and } \\
\text { visions }\end{array}$ & $\begin{array}{l}\text { Key words in visions that } \\
\text { are not keywords in missions }\end{array}$ & $\begin{array}{l}\text { Word frequency } \\
\text { data (normalized } \\
\text { to 26) }\end{array}$ \\
\hline 1 & 2 & 3 & 4 & 5 \\
\hline 1 & $15(075)$ & tho tio & & $20(0,77)$ \\
\hline 2 & $15(0, / 5)$ & education & $-{ }^{*}$ & $19(0,73)$ \\
\hline 3 & $14(0,70)$ & - & - & $18(0,69)$ \\
\hline 4 & $13(0,65)$ & research & & $17(0,65)$ \\
\hline 5 & 12 & _* & & $16(0,62)$ \\
\hline 6 & $12(0,00)$ & & & $15(0,58)$ \\
\hline 7 & $11(0,55)$ & $-{ }^{*}$ & $-^{*}$ & $14(0,54)$ \\
\hline
\end{tabular}


Порівняльна професійна педагогіка 5(2)/2015 Comparative Professional Pedagogy 5(2)/2015

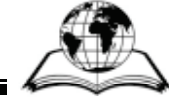

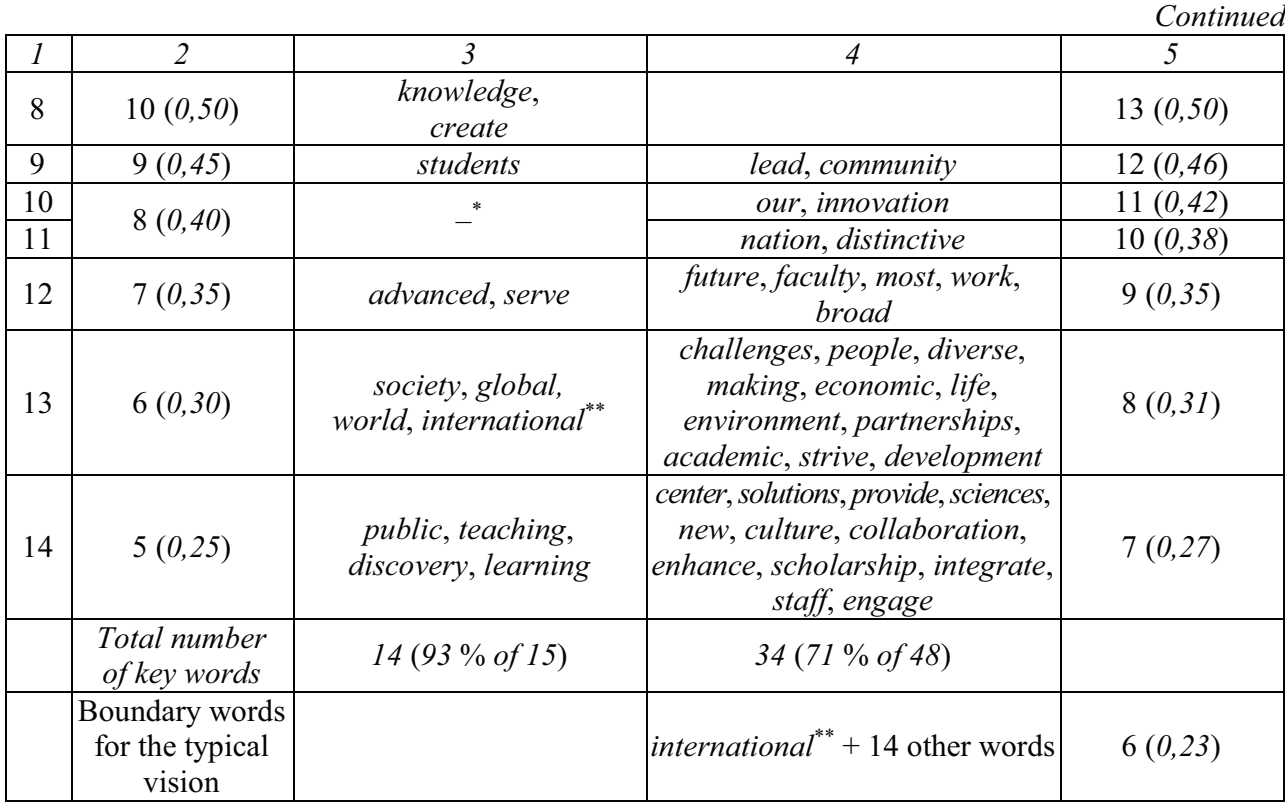

Note: ${ }^{*}$ it means that there were no words with appropriate frequency.

the keyword in missions, which is absent among keywords in visions, but together with 14 other words is a boundary word for the visions (is the next one after the keywords regarding the frequency of use).

As in the case of the missions, the relationship between the presence of keywords in a certain vision and ranking position of the institution is elucidated. Spearman's rank correlation coefficient $\left(K_{c}\right)$ was used to clarify the link between two ranked positions. Calculation of $K_{c}$ for the case dealing with the number of keywords in visions demonstrates the lack of correlation. This is primarily due to the wide range of vocabulary in visions (from 5 to 191 words) and large number of vision keywords (equals 48). Thus, the number of keywords in brief visions is sharply limited while in the lengthy visions there is no such limitation. However, consideration of qualitative composition of visions reveals a positive correlation $\left(K_{c}=0,48\right.$ for $\left.K_{c r}=0,33\right)$ between the ranking position and percentage of keywords. In determining the percentage of keywords - the first method (bulky visions and their "key" contribution to the typical vision) fits with the second method (small visions having keywords). For the University of Wisconsin - Madison, whose vision has the same vision with the typical vocabulary size (of 48 words), both methods are identical. Therefore for ranking - important is a qualitative composition of vision associated with the percentage of keywords.

\section{CONCLUSIONS}

Thus, the visions' evaluation of the top 26 universities in the Shanghai ranking list of the top 30 institutions provides the following conclusions.

First, due to presence of various words in the institutions' visions, they have a wide range: 5 to 191 words, on the average -51 words.

Secondly, regarding the total number of 1315 vision words and 438 different words with an average frequency of use -3 , content analysis reveals a group of 448 key (high- 
frequency) words -48 of which are different words (having average frequency of use -9 ) that essentially describe the vision. They constitute the typical vision.

Third, in comparison with the visions, under the relevant characteristics, the missions are threefold concise. All keywords in the missions, except one, are present in the list of words for the visions. The main (most high frequency) keywords in the visions are "world", "research", "students", "education" and "knowledge". Each of these words is present in half and more than three quarters of visions. For the missions such words are "education", "research", "knowledge" and "create" and they also have the same degree of use.

Fourth, the basic differences in visions' and missions' content occur through the words which have less frequency of use (less significance).

Fifth, as in the case of the missions, the visions' qualitative composition (the percentage of keywords) is positively correlated with the place of the top-rating institution in the ranking list.

The further analysis of the specificity of missions and visions of the world-class universities should include the analysis of values, which are the guiding principles of world's leading higher education institutions. This is necessary for effective modernization of higher education system in Ukraine in line with the trends of civilization.

The author expresses her gratitude to the Doctors of Pedagogical Sciences V. I. Luhovyi and Zh. V. Talanova for their discussion of the findings represented in this article.

\section{REFERENCES}

1. About the Harvard Graduate School of Education. (2014). Retrieved 15.07.2014 from : http://www.gse.harvard.edu/about/index.html.

2. Academic Ranking of World Universities. (2014). Retrieved 25.08.2014 from: http://www.shanghairanking.com/ARWU2014.html.

3. Caltech. (2014). Our Vision. Caltech. Retrieved 15.07.2014 from: http://www.caltech.edu/content/our-vision.

4. Cornell University. (2014). University Mission. Retrieved 15.07.2014 from: http://www.cornell.edu/about/mission.cfm.

5. ETH Zurich. (2014). Strategic orientation 2012-2016. Short version. Self-image. Retrieved 6.05.2014 from : http://www.ethz.ch/en/the-eth-zurich/portrait/Strategy.html.

6. Global Vision. Global MIT. (2015). Retrieved 14.01.2015 from : http://global.mit.edu/vision/.

7. Harvard Business School. (2014). Mission - About Us - Harvard Business School. Retrieved15.07.2014 from : http://www.hbs.edu/about/Pages/mission.aspx.

8. Harvard School of Engineering and Applied Sciences. (2014). Mission Harvard School of Engineering and Applied Sciences. Retrieved 15.07.2014 from: http://www.seas.harvard.edu/about-seas/mission.

9. Harvard School of Public Health. (2014). Mission \& Objectives. About HSPH. Harvard School of Public Health. Retrieved 15.07.2014 from: http://www.hsph.harvard.edu/about/.

10. Imperial College London. (2015). Mission, vision and themes. Retrieved 17.01.2015 from : http://www.imperial.ac.uk/about/leadership-and-strategy/mission-and-strategy/strategy2014/mission/.

11. Johns Hopkins University. (2015). JHM Vision, Mission and Core Values. Retrieved 6.05.2015 from :http://www.hopkinsmedicine.org/strategic_plan/vision_mission_ values.html. 
12. Kyoto University. (2015). Vision and Long-Term Goals. Retrieved 15.01.2015 from : http://www.kyoto-u.ac.jp/en/about/operation/long-term.html.

13. Teacher College Columbia University. (2015). Our Future. Retrieved16.01.2015 from : http://www.tc.columbia.edu/campaign/ourfuture.

14. The University of California, San Diego. (2014). About UC San Diego. Retrieved 15.07.2014 from : http://www.ucsd.edu/explore/about/index.html.

15. The University of Chicago Medicine and Biological Sciences. (2014). Mission, Vision, and Values. Retrieved 5.09.2014 from http://bsddiversity.uchicago.edu/page/mission-vision-and-values.

16. The University of Tokyo Charter. (2015). Retrieved 6.05.2015 from: http://www.u-tokyo.ac.jp/en/about/charter.html.

17. The will and the way. (2015). Northwestern University Strategic Plan 2011. Retrieved 7.05.2015 from : http://www.northwestern.edu/strategic-plan/docs/strategic-plan.pdf.

18. University College London. (2014). Mission, vision, values and guiding principles. Retrieved 16.07.2014 from : http://www.ucl.ac.uk/white-paper/mission.

19. University of California, Berkley. (2014). Facts at a glance - UC Berkeley. Retrieved 1.09.2014 from : http://berkeley.edu/about/fact.shtml.

20. University of California, Los Angeles. (2014). UCLA Mission \& Values. UCLA. Retrieved 15.07.2014 from : http://www.ucla.edu/about/mission-and-values.

21. University of California, San Francisco. (2014). Mission \& Vision. Retrieved 11.01.2014 from : http://www.ucsf.edu/about/mission-vision.

22. University of Chicago. (2014). Library Mission, Vision and Values. Retrieved 5.09.2014 from : http://www.lib.uchicago.edu/e/about/mvv.html.

23. University of Illinois. (2014). Mission \& Vision. Retrieved16.07.2014 from : http://www.uillinois.edu/about/mission.

24. University of Michigan. (2015). U-M Accreditation 2010: Mission and Integrity. Retrieved 15.01.2015 from : http://www.accreditation.umich.edu/mission/index.php\#Vision Statement.

25. University of Minnesota Twin Cities. (2015). Vision and Goals. Strategic Plan Implementation. Retrieved 7.05.2015 from : http://strategicplanning.umn.edu/p/vision.html.

26. University of Oxford. (2015). Strategic Plan 2013-18 - Vision - University of Oxford. Retrieved 6.05.2015 from : http://www.ox.ac.uk/about/organisation/strategic-plan.

27. University of Pennsylvania. (2015). Strategic Framework for Penn's Global Initiatives 2012-2017. Retrieved 13.01.2015 from: http://www.upenn.edu/almanac/volumes/v59/n14/for-comment.html.

28. University of Toronto. (2014). Mission \& Purpose. University of Toronto. Retrieved 16.07.2014 from : http://www.utoronto.ca/about-uoft/mission-and-purpose.

29. University of Wisconsin - Madison. (2015). Our Vision. Retrieved 6.05.2015. from : http://www.wisc.edu/about/introduction_to_uwmadison.pdf.

30. University of Wisconsin. (2014). Vision and Values. Discover the UW. Retrieved 15.07.2014 from : http://www.washington.edu/about/visionvalues/.

31. Yale Information Technology Services. (2014). Vision, Mission, Values, and Principles. Retrieved 5.09.2014 from : http://its.yale.edu/about/organization-withinits/vision-mission-values-and-principles.

32. Yale University. (2014). About History. Retrieved 5.09.2014 from: http://www.yale.edu/about/history.html. 
33. Yale University. Office of the President. (2014). Welcome. Retrieved 5.09.2014 from : http://president.yale.edu/.

34. Луговий, В., Калашнікова, С., Слюсаренко, О., Таланова, Ж. (2013). Нобелівські лауреати і топ-заклади вищої освіти, країни та континенти з передовим університетським потенціалом [Nobel laureates and top higher education institutions, countries and continents with leading university potential]. Вищза освіта Украӥни [Нigher education of Ukraine], No. 4, p. 10-20 (in Ukrainian).

35. Слюсаренко, О. (2014). Гарвард іде у відрив: динаміка і стратегії розвитку топ-закладів вищої освіти у світі [Harvard's Breakaway: Dynamics and Strategies for the Development of Top Higher Education Institutions in the World]. Вища школа [Higher School], No. 10, p. 40-52 (in Ukrainian).

36. Слюсаренко, О. (2014). Стійкі групи, зразкові моделі, ефективні стратегії закладів вищої освіти світового класу [Stable Groups, Exemplary Models, Effective Strategies of World Class Higher Education Institutions]. Освітологія: украӥнсько-польський науково-методичний щорічник [For Education: Ukrainian-Polish scientific and methodical yearbook], No. 3, p. 75-81 (in Ukrainian). 